\title{
DISCOURSE, AUTHORITY AND MEDIATION IN AN ETHNOGRAPHIC ENCOUNTER IN EASTERN MEXICO
}

\author{
Minerva Oropeza-Escobar
}

\begin{abstract}
Although the discursive construction of authority has been largely investigated for different kinds of interaction and settings, studies concerned with authority in ethnographic encounters are scarce. In the present article, I demonstrate that in this kind of encounters the mediational character of the interactants' roles and the transcendence of the co-constructed text with respect to the current event play a crucial role in the construction of authority through discourse. My data consist of two events in 1990 recorded as part of a research project on beliefs and ritual practices among the Totonac population in Eastern Mexico, as well as the corresponding field notes. While my focus is on the linguistic and discursive resources used in the recorded sessions, I demonstrate that a well-founded account also involves a previous event, in which the methodological tools and interactional dynamics were negotiated, as well as a rehearsal previous to each recording session proposed by my consultant as a means to ensure the relevance of the information and the appropriateness of its delivery.
\end{abstract}

Keywords: Authority; Discourse; Field research; Mediation; Mexico.

\section{Introduction}

Interaction in ethnographic encounters and interview settings has been approached from several perspectives. One line of inquiry deals with the asymmetry of the roles played by interviewer and interviewee, and how a more egalitarian and collaborative situation could be achieved (Mishler 1986; Cameron et al. 1992). Mishler (1986), for example, has called our attention to the fact that most interviewing practices rely on a behaviorist conception that identifies questions and answers with stimuli and responses, respectively. This position, Mishler points out, does not allow the researcher to appreciate the interpretive efforts of the respondents to answer questions in a coherent, relevant and meaningful way. He advocates the empowerment of respondents, their consideration as collaborators in a common endeavor, as a means to overcome the asymmetric relationship characteristic of interview situations.

The methodological need to investigate the metadiscursive practices of the speech community under study, so as to achieve a less intrusive and more fruitful interaction with our consultants has been a concern for linguistic anthropologists. Thus, Briggs (1986) discusses the interaction between ethnographer and consultant in interviewing situations in the light of his field-research experience. Especially illustrative is his critical analysis of the "communicative blunders" he committed. The field worker, he maintains, should explore how the people s/he studies interact and gain access to knowledge in everyday settings and situations. This would allow the 
ethnographer to become familiar with local metacommunicative norms, and, accordingly, to adopt more socially, culturally and linguistically sensitive research techniques (Briggs 1986). Maranhao (1993), for his part, discusses his interaction with his consultants during his field-research on natives' fish classification in Brazil. For him as researcher, discursive fluency in the sense of ability to verbalize was the major evidence for knowledge. For his consultants, on the other hand, knowledge was best represented through practice, while text was instead a representation of virtue, a prototypical expression of heroic actions. Maranhao reflects not only on the resulting conflict of perspectives and expectations, but also on the anthropological importance of recognizing that cultural values attach to modes of communication.

Some work has been concerned with the role of the ethnographer and the tape recorder in the course of the interaction and the shaping of discourse, thereby highlighting the conditions under which ethnographic data and anthropological knowledge itself are co-constructed by researcher, consultant, and by the broader audience projected by the tape recorder. In an early work, Labov (1972) notes a correlation between interview situation and formal style, and reflects on its methodological implications. Formal style in Labov's case can be seen as a particular way of keying performance (Bauman and Briggs 1990), because of its highly reflexive and specially marked properties. In studying different renderings of what thematically can be seen as the same story, Hymes (1975) observes the importance of the ethnographer in the way the interaction is framed by the consultant as well as in the interplay of performance with other frames, such as report and translation, in the same speech event. In a similar vein, Tedlock (1983) and Bauman (1986) focus his attention on the role of both the researcher and the tape recorder in the narrative and metanarrative structure of storytelling events, while Mannheim (1998) discusses the role of the ethnographer as co-participant in the shaping of conversational narratives. The study of disclaimers of performance (Bauman 1993) makes it possible not only to arrive at a better understanding of the nature of performance, but also to view ethnographic encounters as the result of a negotiation between ethnographer and consultant.

The performance nature of the consultant's speech in interview settings has also been discussed. Performance here has been understood in at least two different ways: As either referring to the consultant's tendency to shaping discourse in accordance with the researcher's expectations (Haring 1972), or to his/her joking or speaking figuratively during the interview (Paredes 1977). Paredes demonstrates that the lack of awareness, on behalf of the researcher, of the performance nature of the consultant's speech and the consequent literal interpretation of his/her answers can drive the analysis in the wrong direction.

The present article views the interaction between researcher and consultant from a different angle, namely the negotiation and discursive construction of authority in ethnographic encounters. In so doing, I establish a link between two research traditions: The study of interaction in ethnographic encounters and interview situations - briefly summarized above -, and the discursive construction of authority.

Although the construction of authority through discourse has been largely investigated for different kinds of interaction and settings (i.e. interaction in the classroom, courtroom and bureaucratic settings; in everyday conversation, performance discourse and ritual speech), studies concerned with authority in ethnographic encounters are scarce. The studies available deal with the shortcomings of the interview format, its ideological bias, the resulting asymmetry of the interviewer and 
interviewee's roles (Mishler 1986), and also the interviewee's refusal or unwillingness to engage in surveys in those cases in which the interview format does not match a speech event within his/her own linguistic repertoire (Wolfson 1997).

My analysis differs from these studies in two respects. First, my focus is on the relation between authority, mediation and entextualization. I demonstrate that in this kind of encounters the mediational character of the interactants' roles and the transcendence of the co-constructed text with respect to the current event play a crucial role in the interactional dynamics and the construction of authority through discourse. While my major concern is with the linguistic and discourse resources used by my consultant in two recorded events, I show that a well-founded account involves the previous events in which the methodological tools were negotiated, and also a rehearsal previous to the recording sessions, proposed by him. From the perspective of the data analyzed, previous work relies on data in which either (a) the consultant somehow adjusts to the overall structure and interaction proposed by the researcher - inappropriate as they may be - and manages to answer the questions posed by the researcher or to engage in the talk conducted by him/her, or (b) the consultant refuses to participate at all. In my case, although my consultant agreed on participating in the research I conducted, he suggested major changes to the kind of interaction I had in mind, in such a way that an entirely different event and form of discourse finally resulted. My data consist of two recorded events carried out in 1990 as part of a research project on beliefs and ritual practices among the Totonac population in Eastern Mexico, as well as the corresponding field notes.

\section{The interaction and the participants}

During the Spring 1990, I was a master's student of social anthropology in a Mexican research center, carrying out a project on beliefs and ritual practices among the Totonac population of the State of Veracruz (Eastern Mexico). Local authorities and people in one of the communities I studied suggested that I visit a man who was then about seventy years old, who was then one of the few remaining Totonac speakers in his town (Yecuatla), and was considered a kind of chronicler. I contacted him as soon as possible to let him know the purpose of my research, and to encourage his participation. Don Melquíades agreed to provide me with the information I needed. We can say that this was the first responsibility he assumed. Yet, his responsibility extended soon to the methodology that should be employed for eliciting information. Indeed, Don Melquíades disapproved of my initial proposal to carry out an open-ended interview. He asked me, instead, to make a written interview schedule or outline that he could use to guide his participation. A few days later, I came back with an interview schedule focused on two thematic domains: Different stages in the human life cycle (marriage, birth, childhood, youth, adulthood, old age and death), and natural phenomena and entities (rain, thunder, rainbow, eclipse, rivers, caves, lakes, and so on). I orally mentioned that my major interest was in the beliefs and practices related to these thematic domains in the Totonac tradition and explained that, since the conception of the human life cycle and of natural phenomena and events differs from one culture to another, it would be hard for me to develop the guide in a more detailed way. The rationale underlying my decision was also that it was important, for methodological reasons, to guarantee as much spontaneity as possible in my consultant's answers (cf. 
Cameron et al. 1992 for a discussion of this methodological position). Don Melquíades accepted the schedule and, in addition, proposed a rehearsal, so that before the recording sessions I could suggest changes to any aspect of his delivery. The rehearsal and the recording sessions lasted around thirty minutes each. He decided to stop as soon as he had addressed all the topics about the human life cycle. Then he asked me to return another day in order to work on the second part of the schedule. The second elicitation session, on day three of our work together, was similar to the previous one, with a rehearsal prior to the recording session.

\section{A dialogue between mediational actors}

In the epilogue of his most recent work, Bauman (2005) refers to a number of cases in which performers or interviewees express their wish that the recorded interaction transcends the current event, so that a broader audience can appreciate their skill, take advantage of their experiences, or have access to their cultural practices. In so doing, they explicitly acknowledge the mediational character of the ethnographer.

In what follows I demonstrate that awareness of this character contributes critically to the course of the interaction and to the shaping of discourse, and that a factor equally important is the consultant's conception of himself as a mediator. Ethnographic encounters are thus to be seen as a dialogue between mediational actors.

\subsection{Discourse, metadiscourse and mediation}

The starting point for my analysis is Don Melquíades' initiative to rely on a written questionnaire rather than an open interview and to carry out a rehearsal prior to the recording sessions. I show that the interplay of authority, language ideology, and face (Goffman 1967, 1971; Brown and Levinson 1987) is actively involved in these decisions.

Don Melquíades' suggestion to rely on a written means rather than on a face-toface exchange can be seen to be based on a number of reasons. A lack of correspondence between the interview format proposed by the researcher and a discourse genre or speech event identifiable for the consultant as a member of a particular speech community gives rise to different reactions. Such reactions vary from discomfort and uncertainty with regard to the course of the interaction and the seemingly unclear goals of the research, to the request that the researcher develops a written schedule, so as to keep a clear focus and present the interviewee with straightforward questions. Wolfson (1997) attributes these reactions to the fact that, while formal interview is a speech event for her interviewees, spontaneous interview is not.

Another factor that could have played a role is Don Melquíades' experience in previous research. The fact that he had participated in several scholarly studies, including a linguistic study focused on phonetic and lexical aspects of Totonac, a project aimed at eliciting the Totonac names of the human body parts, and research on the evolution of the boundaries of his community could have driven his preference in such a direction, since these studies probably involved written or graphic elicitation tools, such as word lists, drawings or maps. 
In my opinion, these circumstances should be seen in association with other factors, in particular with Don Melquíades' concern with setting up the best possible conditions for the production of a text that could be positively evaluated by the broader (mostly scholarly) audience projected by the tape recorder. The possibility to base his participation on a written schedule, allowed him to get a clearer idea of the topics to be addressed, and, also, to gain some valuable planning time. My interpretation is supported by (a) the fact that he also suggested a rehearsal consisting in addressing some of the topics listed in the schedule, before I started to record, and (b) that he asked me to express my opinion about the relevance and appropriateness of his answers. These initiatives demonstrate not only that he was concerned with producing a highly consistent piece of discourse, but also that he was ultimately performing for the broader audience that could have access to the recordings, rather than for me as his current addressee. They also show that the audience projected by Don Melquíades would adjust to similar evaluative parameters to those I would rely on.

A concurrent factor has to do with language ideology. Literature on ritual speech, in which authority plays a crucial role, has revealed that one of the distinctive properties of that kind of speech is to be kept markedly apart from the norms of everyday interaction and ordinary experience (Bloch 1974; Du Bois 1986). In the encounters at issue, one of the most evident results of Don Melquíades' reliance on a written document is the turn organization of the event. As soon as I presented him with the brief research schedule I had developed, he took it in his hands and based his participation directly on it, carefully addressing each topic, and leaving little room for a more interactive kind of event. In both recording sessions verbal exchanges were limited to a greeting formula at the beginning and a brief formulaic statement by me at the end to thank Don Melquíades for his participation. This rather monologic form of discourse could have been deemed by Don Melquíades as more authoritative than a face-to-face verbal exchange, closer to everyday communication.

Don Melquíades' prestige and recognition in his own community and in scholarly circles outside his local area, is another factor that, in my view, could have driven his interactional preferences. The basis of such recognition is his being a gifted, bilingual speaker, his expertise in the ancient Totonac language and culture, and his knowledge of the history of his community. All these capabilities had afforded him the opportunity to participate as a consultant in a university in central Mexico. His exposure to scholarly discourse and class dynamics very likely exerted also an important influence on his way of speaking and interacting. In addition, Don Melquíades' engagement in scholarly activities can be seen to involve both a personal and a social dimension. From a personal point of view, he was proud of his cultural and linguistic background - as mentioned earlier, he was actually one of the few remaining Totonac speakers in his community, and even in the broader region to which Yecuatla belongs and enjoyed sharing his knowledge with foreigners and young people in his community. He was frequently invited by local authorities to welcoming important visitors in public meetings. In those meetings he usually delivered his speech in Totonac and Spanish.

From a social point of view, his being a public person and a representative of his culture entailed a concern with his self-image or face. As made evident by my analysis, he not only presented himself through his texts as a knowledgeable consultant and a 
skilled speaker, but also as a polite, modest and helpful person ${ }^{1}$. This becomes especially evident in the opening and closing sections of his delivery, where he greets me, welcomes me, and expresses his wish that the information he provides be helpful for the achievement of my scholarly goals. A similar treatment can be appreciated in the consistent use of formal pronouns and academic degree, as forms of address as well as his explicit acknowledgment of his limitations in dealing with specific details of some topics.

Thus, such features as the turn organization of the interaction, the reliance on a written document rather than in a face-to-face interaction, as well as Don Melquíades' formal register and polite treatment, among other features, can be seen as inextricably linked to the transcendence of discourse with respect to the current setting and addressee, associated to the mediational role of the ethnographer.

Interestingly enough, although his background and profile was crucial for him to become a consultant, being a consultant, in turn, has afforded him prestige. Such prestige, seen from the perspective of people in his village, does not necessarily rely on the specific content or formal consistency of the texts produced during the interviews or ethnographic encounters in which Don Melquíades engaged. The reason for this is that such texts are not necessarily disseminated among villagers, but among members of scholarly circles, as will be discussed below. Consequently, Don Melquíades’ prestige among people from the village, resides in his constantly being invited to participate in events organized by or for visitors interested in the history, culture and indigenous language, or in meetings in which reference to the Totonac roots of the inhabitants were deemed relevant.

Thus far, I have argued that the consultant's perception of the ethnographer as a mediator in a larger chain of events is crucial to an understanding of ethnographic encounters. Now I focus on the equally decisive effect of the consultant's conception of himself as a mediator.

\subsection{Mediation and construction of authoritative discourse}

The participant's awareness of his mediational character affects discourse and interaction at different levels, from its overall properties to highly specific details. In a dialogue between mediational actors, the nature of the authority that each of them claims for himself is inextricably linked to the authority s/he attributes to the other(s).

Don Melquíades' authority, as expressed consistently through metadiscursive elements ${ }^{2}$ and ultimately through discourse structure, does not rely on the propositional content of his words, but rather in the entextualization of others' knowledge on the basis of my particular needs as researcher. In the following excerpt, he represents himself as a

\footnotetext{
${ }^{1}$ In accounting for the unwillingness of a storyteller to take responsibility for specific traditional narratives, Bauman (2005: 127) acknowledges the relevance of the notion of face: "Given that storytelling in the La Have Islands - as in so many other places - was a privileged means of constructing and presenting oneself as a person of social worth, what was at stake, potentially, in failed performance was a loss of face."

${ }^{2}$ I use this term in a sense similar to metanarrative elements. Since Don Melquíades speech is not narrative discourse strictly speaking, as I discuss below, the term metanarrative seems inappropriate for my analysis.
} 
transmitter of what was said by people who lived in the past, and witnessed how things were then ${ }^{3}$.

\section{\{NATURE excerpt 1$\}$}

Yo ahora me lo explico lo que realmente antes me han platicado...pues aquellos hombres que ya vivieron la experiencia, que ya se dieron cuenta. $Y$ yo solamente en este momento le estoy contestando. Pues yo soy ahorita un transmisor de aquellos hombres que me contaron.

'And now I can understand what I have been told before...well, by those men who already experienced, who already realized. At this moment, I am just answering. Right now I am a transmitter of those men who recounted it to me.'

As transmitter, he compares himself to other persons in his community who, in the past, have acted as a channel for other experience and knowledge. In excerpt 2, which comes right after excerpt 1 , he represents himself as part of a process that has developed over time:

\{NATURE, excerpt 2\}

Sólo a mí me platicaron los hombres yecuatecos nativos, y que también ellos así les platicaron, tal vez desde hace muchos años...

'TheYecuatecan native men only spoke to me, and so too they were spoken to, perhaps many years ago.'

Throughout his delivery, Don Melquíades allocates responsibility and acknowledges authority for those elements that in his view play a role in our interaction. First of all, Don Melquíades explicitly attributes authority for knowledge or propositional content to either a specific person, an identifiable sector of his community, or an abstract entity such as tradition. In the previous excerpt, los hombres yecuatecos 'the Yecuatecan native men' appears as the source of his knowledge, while in 3, below, it is la creencia 'the belief' that is the source of the Yecuatecan beliefs associated with comets:

\{NATURE, excerpt 3\}

Cuando la cometa sale, según la creencia, puede haber guerras, puede haber grandes enfermedades, puede haber calamidades.

'According to belief, when a comet appears there can be wars, terrible sicknesses, disasters.'

A tendency to situate authority for the message in a remote source, whether ancestors, mythical heroes, or another entity has been reported in literature dealing with cross-

${ }^{3}$ My transcription notation does not differ from the punctuation devices employed in written Spanish and English, except that I employ three dots in parentheses when I omit part of the discourse transcribed. The name of the file, to which the corresponding excerpt belongs, is provided in caps within curled brackets. 
cultural features of performance events and ritual speech (Bauman 1977; Du Bois 1986) ${ }^{4}$. Authority is thus transferred from a proximal speaker or source to a prime speaker (Du Bois 1986), who is responsible either only for the intentions of the message or also for its entextualization. In the events analyzed for this article, it is authority for propositional knowledge that relies on a person or entity different from Don Melquíades, while entextualization (Bauman and Briggs 1990) is his own contribution. Metadiscursive elements, consisting of either comments or clauses framing reported speech, are means consistently employed to that end. In excerpt 4, below, he locates authority in a particular group of the population, namely midwives. The framing clause, which appears in boldface type, is the entextualization means he chooses to employ.

\{LIFE, excerpt 4$\}$

$Y$ una vez que nace esa criatura, y si tenía su cordón en el pescuezo, o como si formara carrunera, entonces la matrona decía: "Ah, es niño. Este va a ser, va a ser un revolucionario, va a ser un militar”. Eso eran sus creencias.

'And once the baby is born, if he had the (umbilical) cord around his neck, or forming a sort of cartridge belt, then the midwife said: "Oh, it is a boy. He is going to be, he is going to be a revolutionary, he is going to be a soldier”. That was her belief.'

Here, Don Melquíades quotes the words of midwives in general, in spite of the fact that he uses the third person singular. In other words, he employs the third-person pronoun and corresponding verb form generically.

As tends to be the case for ritual speech and other forms of performance discourse, authority for the knowledge or propositional content invoked is transferred to a person or entity seen by Don Melquíades as either higher in status, or more reliable than himself. For most of the topics addressed, a specific person, an elder called José, is credited as the source of Don Melquíades’ knowledge:

\section{\{LIFE, excerpt 5$\}$}

Había un señor que nos llevabamos mucho, en buena amistad (...) y esto fue lo que me dijo, la historia que ya tenía como cien años atrás, como vivía la gente (...). Se llamaba Pascual José, de los meros nativos yecuatecos.

'There was a man I got along with. We were good friends (...), and this was what he told me, the history that happened a hundred years ago, how the people lived (...). His name was Pascual José, (who was) an authentic native Yecuatecan.'

As made evident in this fragment, Don Melquíades' strongest and ultimate source of knowledge for most of his knowledge is los meros nativos yecuatecos 'the very native Yecuatecans'; in other words, the authentic Totonac people in his community. He emphasizes this source through paralinguistic means (intonation and stress).

Another feature that confers authority to Don Melquíades and his prime speakers for the transmission of knowledge is their competence in Totonac. Thus, Don Melquíades stresses that he obtained most of his current knowledge on ancient traditions and beliefs by interacting with elders in Totonac. He even provides finer details about

\footnotetext{
${ }^{4}$ Other textual means have also been reported, such as the use of vocatives, reference to mythical places, mention to the place where the text was inspired, and so forth (Bauman 2005).
} 
the conditions under which such knowledge was transmitted to him, as illustrated by the following metadiscursive comment:

\{LIFE, excerpt 6\}

Maestra, toda esta información que le he estado diciéndole es con fecha del...más o menos del mil ochocientos sesenta, setenta. Porque en el año mil novecientos treinta había un señor que...nos llevábamos mucho, en buena amistad. El platicaba en Totonaco, y yo también, perfectamente bien. $Y$ nos conversábamos cosas de la vida. $Y$ esto fue lo que me dijo, la historia que ya tenía como cien años atrás, cómo se vivía la gente. El le contó su señor padre.

'Maestra, all this information I have been talking about can be dated...more or less to eighteen sixty, seventy. Because in nineteen thirty there was a man who...I got along with. We were good friends. He spoke in Totonac, and so did I perfectly well. And we spoke about life. And this was what he told me, the history that happened one hundred years ago, how people lived then. It was his father who told him.'

First, he frames the topic he has been previously talking about, by providing the approximate period of time in which the cultural practices he is describing were in force. Second, he mentions how the man who allows him to access the information about the old practices of the Totonac population in turn got the information. Finally, Don Melquíades provides some of the personal characteristics of his prime speaker, and the kind of relationship they had.

Don Melquíades is therefore responsible not only for the wording of the message, but also for its entextualization in Spanish. He bridges not only a time gap, but also a linguistic and cultural gap. This bridging act adds to those identified by Bauman (2005) for many performance genres, which involve time, space, world and status.

Yet not only authority for propositional content resides outside Don Melquíades: The source of authority for the topics to be addressed during the speech event is the researcher. Don Melquíades explicitly attributes to me the authority for the 'questions' posed to him in the schedule in the metadiscursive section that opens the interaction as well as in the metadiscursive elements that mark the shift to a new topic.

\{NATURE, excerpt 7\}

Sobre las estrellas...que usted me pide, maestra, le voy a contestar su pregunta.

'Regarding the stars...as you are asking me, maestra, I am going to answer your question.'

The circumstance that the topics that motivate the interaction were chosen by an external source reinforces Don Melquíades' responsibility for the entextualization 
process. The entextualization process not only links others' knowledge to my particular research needs ${ }^{5}$, but allows him to embody his authority.

The entextualization process involves the use of metadiscursive elements consisting either of whole sections (opening and closing) or comments interspersed throughout the text. This is one of the resources Don Melquíades employs to relate discourse, authority and mediation ${ }^{6}$. In other words, it is through metadiscursive elements that Don Melquíades explicitly reflects on his own role as a mediator, and refers to the source of his knowledge and the conditions under which such knowledge was achieved. Yet, if metadiscourse plays a decisive role in the construction of authority, discourse structure is not less important. The formal properties of speech have been demonstrated to be a powerful means for building authority and enhancing rhetorical power in ritual speech and other performance genres. Formal features identified cross-culturally which accomplish this function have been found to vary from syntactic and semantic parallelism, to special paralinguistic features, to the use of a special register or code (Bauman 1977; Du Bois 1986), to mention just a few possibilities. In studying other kinds of interaction and forms of discourse, scholars (Matoesian 1999; Bucholtz and Hall 2004) have pointed out that an authoritative identity can be constructed through formal properties of speech. In other words, employing a speech associated with a particular social sector, profession or institution helps its members to present themselves as authoritative and knowledgeable.

Confronted with the transcendence and consequentiality of discourse with respect to the current event, and having entextualization as a major contribution and the locus of his authority, Don Melquíades proposed an interactional dynamics that allowed him to produce a highly reflexive and cohesive text. A first and crucial step in that direction was gaining control over the interactional configuration of the speech event, especially the turn organization. Consequently, a long monologue with only a brief turnexchange in the opening and in the closing sections resulted. ${ }^{7}$ A second step was the production of a clearly delimitated and internally structured piece of discourse that included an opening and closing section, and a similar internal structure for each of the topics listed in the schedule. Let us examine the main aspects of this discourse structure.

In both the opening section and some of the metadiscursive comments, Don Melquíades makes explicit the purpose and setting of the speech event, the character of his participation and the role of the researcher. In the following excerpt, he overtly states the researcher's purpose and alludes to his own commitment to answer the questions I posed, to the best of his abilities.

${ }^{5}$ Indeed I was indirectly involved in entextualization when, before I started to record, Don Melquíades rehearsed addressing some of the listed topics, and asked my opinion concerning the appropriateness of his treatment.

${ }^{6}$ Metadiscursive comments tend to be framed by a pause, by a pragmatic breakage in the use of deictics and pronominal forms as well as by the introduction of a subordinate marker such as porque 'because', in contexts in which it does not act as a link between subordinate and main clause.

${ }^{7}$ For the second recording session, Don Melquíades asked me to open the interaction, by mentioning the purpose of the encounter. This decision can be seen not only as a means to endow the event with a higher degree of interactivity in terms of turn exchanges, but also as enhancing his own authoritative position. In other words, it is no longer he who explains to the target audience what the encounter is all about, but directly the researcher. Otherwise, the session was organized in a very similar way to the first. 
\{LIFE, excerpt 8\}

Me da mucho gusto en conocerla por primera ocasión en que Ud. viene a visitarme a mi casa, haciéndome unas preguntas.

...En vista de lo que yo pueda contestarle lo haré con mucho gusto, maestra.

'It is really nice to meet you for the first time you come to my house to visit me, in order to ask me some questions.

...I will do my best to answer you, maestra.'

The assertion that I am visiting him for the first time, our first meeting ever, is incorrect, since I had visited him once before. Unless he is speaking in more general terms to refer to the first time I have done field research in the community. This can be seen as making the event appear more remarkable or memorable, so as to exert a stronger impact on the audience.

In the closing section of the speech event on the life cycle he expresses his wish that his speech be helpful for the development of my thesis. In so doing, he overtly links the current text to my M.A. thesis, making evident the projected intertextuality of the current speech.

\section{\{LIFE, excerpt 9\}}

Maestra, no puedo darle más explicaciones sobre el tema. Lo poquito que yo sé...es que usted las tome a bien mis palabras y que les dé el buen uso a lo que usted está formulando su tesis, maestra.

'Maestra, I cannot give you more explanations about this subject. The little I know....is that you welcome my words, and that you use them appropriately according to what you are pursuing, (that is) your thesis.'

As mentioned above, the closing section is one of the places throughout his delivery in which Don Melquíades projects modesty and politeness more evidently.

By employing the terms coherence and cohesion I do not mean to suggest that the corresponding piece of discourse can be identified with a particular discourse genre available in the consultant's cultural repertoire. Indeed, the discourse constructed in the ethnographic encounter can be broadly characterized as "secondary" in that it articulates or incorporates different discourse forms and resources, such as greetings, farewells, anecdotes, instances of reported speech, etc. We can hardly speak of genre (Bauman 2001) in this case, since a certain degree of conventionality and recurrence are absent from the piece of discourse under study.

As previously mentioned, such piece of discourse is bounded, as a whole, by the opening and the closing metadiscoursive sections. Beyond these two sections, the major discourse unit in Don Melquíades discourse is that of the topics listed in the schedule. The internal structure of each topic usually includes a report of the Totonac beliefs or practices that opens each of the listed topics. This part of Don Melquíades's delivery can be characterized as expository discourse, as illustrated in the following fragment in which the Totonac population's practices during the late eighteenth century and the first half of the nineteenth century are described. 
\{LIFE, excerpt 10\}

Lo que hacían es de la siguiente manera. De que el joven veía a una muchacha. No podían ponerse de novios o tener alguna plática amorosa, sino que los padres eran los que hacían el compromiso. Iban a pedir la mano de la muchacha por primera vez, por segunda vez, por tercera; y en la cuarta vez ya le daban el sí.

'What they used to do was as follows. The boy looked at the girl. They could not go out together by their own decision, not even to talk about love. It was the (his) parents, who set up the engagement. They asked for the girl's hand in marriage for the first time, for the second time, for the third one. And it was the fourth time, when they said yes.'

A comparison between the past and the current situation in the village, another frequent element in the internal structure of each topic, is also made. In excerpt 11, which follows immediately excerpt 10, Don Melquíades compares the old dating practices with the current ones.

\section{\{LIFE, excerpt 11$\}$}

El muchacho platicaba con la novia, pero muy respetuosamente (...). Nunca tenía el gusto de tocarla, darle un abrazo, un beso, como en la actualidad, en los jóvenes que en muchos lugares, en las calles, en los parques, en dondequiera, vemos que ya se platican. Según dicen, ahí es donde se desarrolla el amor y el cariño.

'The boy talked to his fiancee, but very respectfully (...) He never had the pleasure to touch her, to give her a hug, a kiss, like they do nowadays. We see that young people talk in many places, on the roads, in the parks, wherever. It is said, it is then when love and affection develop.'

The use of verb tenses and deictics varies consistently with the shift from the past to the current situation, and vice versa. Thus, while the verbs platicar 'talk' and tener 'have' appear in copretérito ${ }^{8}$ (platicaba 'talked' and tenía 'had', respectively), once the comparative expression como en la actualidad 'nowadays' is introduced, the verb tense switches to the present, as illustrated by se platican 'they talk (to each other)'.

His recurrent comparison between the ancient situations, practices or beliefs and the corresponding state of affairs at the moment of the speech event can also be seen as evidence for his commitment to explicitness. It can be seen as an effort on his behalf to make the depicted situation more easily accessible by appealing to situations likely to be more familiar to the audience. In addressing each subject of the thematic schedule, he moves from past to present. The shift is keyed by changing from copretérito (literally, co-past) to present tense as well as by the use of adverbs and expressions such as actualmente "currently", en la actualidad "nowadays", ahora "now", ahorita, "right now", ahorita en la actualidad, "right now, currently". In order to move back to past events, Don Melquíades uses the copretérito and appeals to adverbs or time expressions such as antiguamente "in the past", antes "before", en aquel entonces "then", en

${ }^{8}$ Copretérito is a verb tense that refers to what is called imperfective aspect for other languages, that is, is a tense used to speak about actions happening within a relatively long period of time, as opposed to past tense, which refers to an action completed. 
aquellos tiempos "in the old days". This comparative treatment is amply used by Don Melquíades.

Another element that is employed consistently in addressing each topic is evaluation. While loyal to his intention to inform me about ancient Totonac practices, Don Melquíades overtly distances himself from people who followed some of the practices he depicts. In speaking about marriage and, specifically, about how virginity of the bride needed to be tested and how the result was made public, he expresses his opinion in the following terms.

\{LIFE, excerpt 12$\}$

Entonces el papá del muchacho ya tenía un cuarto propiamente para pasar la primer noche con su esposa. Aquí es donde viene, pues doloroso, penoso de decir, pero así eran las costumbres.

'Then the boy's father already had available a room to spend the first night with his wife. What follows is painful, embarrassing for me to say, but that is the way customs were.'

In most cases, Don Melquíades’ evaluative comments are anticipatory with respect to the specific situation depicted. That is, the evaluative comment precedes the situation he finds morally questionable, thereby highlighting his disagreement. Yet Don Melquíades' evaluation is not always unfavorable toward what people in his community did in the past. There are several cases in which he deems the bygone days better than the current time.

\section{$\{$ LIFE, excerpt 13$\}$}

Me siento orgulloso de aquéllos mis paisanos porque duraban de setenta, ochenta hasta cien anos, y ahorita en la actualidad, jóvenes de catorce, quince anos ya andan, pues...tomando en las cantinas y echando, pues picardías.

'I feel proud of those paisanos of mine, because they lived seventy, eighty or even one hundred years. And currently boys at ages fourteen, fifteen usually go to bars to drink, and swear.'

Here he values longevity not only because it is associated with physical health and strength, but also because it is the result of consistent good behavior, an accomplishment that merits recognition. In the next excerpt, which summarizes the situation of Yecuatecan children in the past, Don Melquíades provides a balanced picture, which results from the interplay of favorable and unfavorable factors.

\{LIFE, excerpt 14\}

Lo que sí no sufrieron de alimentación, porque aquellos niños comían mucha verdura (...) había mucho pescado en los ríos (...) porque no había contaminación en los ríos como ahorita en la actualidad. Entonces, por un lado sufrían de alguna manera, pero por otro lado, estaban bien fuertes los niños. 
'What they did not lack at all was food. Because those children ate a great deal of vegetables (...) There was a great deal of fish in the rivers (...), because rivers were not contaminated as they are nowadays. So, on the one hand, they suffered, in a certain way, but, on the other hand, the children were very strong.'

Thus, Don Melquíades presents himself not as a neutral transmitter of information, but rather as a critical individual, able to agree or disagree with what he is reporting on. That is, he characterizes information not only chronologically or according to the source or process through which he gained access to it, but also from a moral viewpoint.

As to the transition from one topic to another, it is smooth in those cases in which there is an inferable thematic connection between the current and the next topic, as in the case of the life-cycle stages. For instance, pregnancy is seen by Don Melquíades as a continuation of marriage, as one of its major goals, thus creating the conditions to speak about the new topic.

\{LIFE, excerpt 15\}

Entonces, maestra, seguimos haciendo la aclaración sobre del matrimonio. Este matrimonio... usted sabe que lo primero que se busca dentro del matrimonio es que haya hijos. Y se hace embarazada la señora, sin que la vea ningún médico. En aquellos tiempos no había, sino que había parteras.

'Then, maestra, we continue to make the clarification about marriage. This marriage...you know that the first thing, which is looked in marriage for is to have children. And the woman becomes pregnant, without being seen by a doctor. In those days, there wasn't any, but there were midwives.'

The shift from marriage to pregnancy is thus made smoothly, as though the latter were a consequence or goal of the former. The text dealing with the life cycle is very much woven as a continuum, as a sort of chain of interconnected events.

Yet cohesion is achieved not only through thematic continuity or discontinuity: In those cases in which there is not a clear relation between two successive topics, including the transition between the opening session and the schedule properly, a reference is made to the next topic listed in the schedule, with expressions as "With regard to the next question you make" or "here you are asking me about...", which I call 'intertextual reference'. This happens more commonly in the section of the guide dealing with natural phenomena, where it is not always easy to establish a link between the beliefs and practices associated with two successive phenomena on the list, for example, the rain and an eclipse, to mention an extreme case. In these cases, while the treatment of the piece of discourse having to do with nature is similar to the one given to the life cycle, the switch from one topic to the next is made in a more overt way, by appealing to transitional words or expressions. This could be due to the difficulty of linking the gamut of natural phenomena and entities I included in the schedule. As can be appreciated in excerpt 16 below, Don Melquíades alludes to the schedule as a means to move on to the next topic:

\{NATURE, excerpt 16\} 
También aquí usted me hace otra pregunta de... de las nubes. Las nubes, según... de los hombres que creyeron, o hayan sido por medio de su creencia, o por medio de imaginación que ellos tenían, o porque alguien les haya contado a sus abuelos, que el trueno es una persona que traiba unos barrotes ardientes y que por eso hacían los relámpagos.

'Here too, you ask me another question about...about the clouds. Clouds, according to...those men who believed, or it might be through their belief, or through imagination they had, or because somebody had recounted it to their grandparents, the thunder is a person who carried some burning clubs. That is why they produced the lightning.'

In using the deictic aquí "here", Don Melquíades is referring to the written schedule he is handling and looking at as he speaks. A similar strategy is used in approaching the first topic of the schedule after the opening section, as illustrated by the following fragment, taken also from the section of the schedule dealing with nature.

\section{\{NATURE, excerpt 17\}}

Como primer punto, usted me está preguntando sobre de las lluvias o tormenta. Para ver la tormenta, para que se haga una tormenta, como usted me lo pide, primero tiene que haber nubes en el espacio, o sea en el firmamento

'As the first point, you are asking me about rain or storms. In order to see a storm, in order for a storm to take place, as you are asking me, first there need to be clouds in the space, that is, in the firmament.'

In this particular case, Don Melquíades' treatment for the two major thematic domains of the schedule (life cycle and nature) does not differ, indeed. In both cases, an intertextual reference allows him to transit from one structural section of the text (opening) to another (first topic). Excerpt 18 is the first topic dealing with life cycle stages. It comes immediately after Don Melquíades' greeting and welcoming words (excerpt 9).

\section{$\{$ LIFE, excerpt 18\}}

Usted me dice esta pregunta sobre las costumbres de nuestro pueblo de Yecuatla, sobre el cuerpo humano. Quiero expresarle cómo ha venido la creación de nuestro pueblo...

'You are asking me this question, about the customs of our town of Yecuatla, about the human body. I want to express to you how the creation of our town took place.'

Internally, as mentioned earlier, the treatment for each domain is very similar. In both cases, reported speech, a comparison between the present and past situation, and evaluative comments are exploited consistently.

Another cohesive device frequently used by Don Melquíades is the explicit characterization of speech acts. He often announces what is coming next, that is, whether he is going to explain something, to answer a question, to provide information, or to extend a previous comment, as can be seen in fragment 15 seguimos haciendo la aclaración 'we continue to make the clarification.' In excerpt 18 we can appreciate (line 2) that the shift from the previous metadiscursive comment to the first topic (marriage) is 
done by an explicit labeling of the kind of speech act Don Melquíades is carrying out (quiero expresarle 'I want to express to you').

Making a decision on the register to be employed throughout the event, and consequently on the linguistic and prosodic features consistent with such a register is another dimension of entextualization faced by Don Melquíades. Register is an element closely related to both coherence and cohesion (Martin 2003), which confers unity to such linguistic features as lexical choice, forms of address, intonation and pace. That Don Melquíades opts for a formal register can be seen in (a) his use of formal pronominal forms and the corresponding verb inflexion, and my academic degree as a form of address, in a situation in which he could have used the informal corresponding forms, given the age difference between us, (cf. the excerpts included above) (b) lexical choice, which includes items uncommon in everyday conversation, (c) the use of unusual verbs of saying in the framing clause of reported speech.

With regard to lexical choice, the stylistic level of his discourse in general is high, as pointed out above, including words unusual in everyday life - and even in more formal situations - such as firmamento 'firmament', instead of cielo 'sky' or infinito 'infinite', and senectud 'senescence' instead of the more common term vejez for 'old age, ${ }^{9}$ in the following excerpt:

\section{$\{$ LIFE, excerpt 19\}}

Ya de setenta a ochenta en adelante, pues ya entra la vejez, o como se le dice su verdadero nombre, la senectud.

'From age seventy or eighty on, well, old age or, to use its true name, senescence, sets in.'

It is worth noting that Don Melquíades introduces the term senectud after the term vejez - which was used in the thematic schedule - through a metadiscursive comment, explicitly assessing his own term as a more appropriate choice. ${ }^{10}$.

${ }^{9}$ Although I interpreted these words as highly marked as part of performance, it is possible that they are relatively common in specific segments of the Yecuatecan population that could have access to literary sources such as the Bible and other religiously oriented texts.

${ }^{10}$ A fact that deserves closer attention than I can give it here, is the occurrence of a number of linguistic forms that are inconsistent with the formal style and that take place at various linguistic levels (phonological, morphological and lexical). Such inconsistencies could be interpreted as evidence that Don Melquíades is not completely familiar with the style he employs during the elicitation session, and that he is making an effort to reach a level compatible with the one he attributes to his potential audience. Phonological inconsistencies include a pronunciation that is widespread among popular sectors, but differs from educated pronunciation; for example med[e]cina for medicina 'medicine', ciclón Jane [k] for ciclón Janet 'hurricane Janet', among others. Morphological inconsistencies involve verb inflection, especially conjugation of irregular verbs as regular, in such items as quiéramos for queramos 'we want (subjunctive)', and haigan for hayan 'they have (subjunctive)'. Morphological inconsistencies may also involve noun inflection, especially pluralizing of irregular nouns as regular ones, for example mamases for mamás 'moms'. With regard to lexical choice, the word pescuezo 'neck (of animals)' is employed instead of the expected cuello 'neck', which would be consistent with the overall style. Such forms are suggestive of the performance nature of this speech event. However, only a more comprehensive study of the Spanish dialect in this region would lead to a principled interpretation of these features. 
In the following example, the framing clause of reported speech, namely sigue expresándose 'she continues to express herself' indexes a very formal style, in agreement with the accompanying paralinguistic features. Don Melquíades is reporting the advice of a midwife to prevent the negative effect of a lunar eclipse on a baby, which illustrates this situation.

\{LIFE, excerpt 20\}

"Entonces" -sigue expresándose- "cuando estés embarazada, te tienes que poner un alfiler, te tienes que ponerte una cinta roja para que la luna no te vaya a hacer travesuras".

، "Then” -she continues to express herself- "when you are pregnant, you need to use a pin (on cloth), you need to wear a red ribbon, so that the moon does not play pranks (does not affect you)"'.

Although I am not especially concerned with intonation in this paper, I would like to mention that Don Melquíades intonational contour, pace, and careful pronunciation contribute to endow his delivery with formality (CHOICE). The choice of a formal register also interacts closely with the use of polite forms, including greetings, welcoming words, and acknowledgment of personal limitations illustrated above.

To sum up, in order to render his discourse authoritative, Don Melquíades appeals to metadiscoursive elements, to a careful treatment of discourse structure, and to lexical choice and prosodic features, all of them consistent with a formal register. The interplay of these elements would not have been possible without a number of metapragmatic decisions, which include reliance on a written schedule, control of turntaking organization, and rehearsals previous to the recording sessions.

\section{Intertextuality and socialization of knowledge in the ethnographic encounters}

The highly emergent nature of discourse and interactional solutions in the ethnographic encounters under study derives, among other factors, from the fact that, although such encounters are interactively constructed by the interactants, as any other piece of discourse, they are neither the result nor the point of departure of a historical process that engages the interaction of members of the same speech community. In other words, they are not, strictly speaking, the result of the interaction between speakers who share a repertoire of discourse forms and resources that help them orient their interaction, beyond the fact that the encounters were carried out in Spanish. In addition, the resulting discourse is rather aimed at engaging in an intertextual process whose ultimate addressee is a scholarly audience located outside the community. Consequently, these texts, unlike other forms of discourse, usually do not participate in a process of traditionalization (Bauman 2005) ${ }^{11}$. I maintain that this is a powerful reason why discourse in this kind of ethnographic encounter involves highly individualistic and creative solutions. This property is reinforced by the fact that research interests and methodologies differ from one scholar to another, with the consequent limitation in the

11 This does not mean, of course, that specific treatments cannot be rooted in the cultural repertoires of the interactants. 
consultant's possibilities to deal with the current communicative needs on the basis of his/her previous experience, except, perhaps, in its most general aspects.

As mentioned earlier in this paper, one of the reasons why Don Melquíades might feel encouraged to display full communicative competence throughout the ethnographic events analyzed here, is that he is a highly recognized person in and outside his own community, by virtue of his knowledge of the local culture, language and history, and his being a gifted speaker. Why, if the members of his own community will not necessarily have access to Don Melquíades texts, should he be concerned about their appropriateness and quality? How could his performance in this particular ethnographic encounter have an impact on his prestige? As I have pointed out before, there is discursive and metadiscursive evidence that he is rather performing for a mostly scholarly audience projected by the tape recorder, who is certainly likely to evaluate his performance on the basis of discourse ${ }^{12}$. A remarkable difference exists, in this regard, between the ethnographic encounters I study and other forms of discourse, especially performance discourse, since the former does not involve interaction among members of the same speech community. It involves neither recreation of a historically shaped text, genre or event, nor does it, presumably, engage in a process of traditionalization, understood as a historical process that involves the active creation, on behalf of the members of a speech community, of a link connecting current discourse to past discourse.

On the contrary, it is a highly emergent piece of discourse that, while taking advantage of the different discourse forms to which Don Melquíades has been exposed to, both as a member of the Yecuatecan speech community and of the broader scholarly circle with which he has constantly been engaged, exhibits creative solutions at every step of the interaction.

Whereas in performance routines such as those studied by Bauman (2005), traditionalization, socialization of knowledge and authorization are among the metadiscursive processes that performance and intertextuality accomplish, and tend to concur, in the particular case I study, socialization of knowledge and authorization do not involve traditionalization, at least from the perspective of the speech community to which Don Melquíades belongs. It is doubtful that a process of traditionalization takes place in the target audience, although the engagement of Don Melquíades words in an intertextual network is very likely to occur. What I have in mind here is the possibility that at least part o Don Melquíades' discourse can be quoted and successively reinterpreted by other analysts.

Of course, the situation depicted can differ in those cases in which the research involves the participation of the community as a whole or of a specific sector thereof. In these cases, consultants might engage and follow the development of the research from its inception, and have the opportunity to share their experiences with both the investigator and other members of the community or group. Eventually, similar interactive solutions might arise on the basis of shared cultural and linguistic knowledge and of the exposure to common research experience.

While Don Melquíades performance is open to evaluation by members of his own community in public events, it is not the access to the texts produced in his face-toface encounters with researchers that affords him recognition in his community, but

${ }^{12}$ Such evidence includes, among other elements, allusion, in the closing section, to my MA thesis, as the target text which will ultimately incorporate the text in progress. 
rather the fact itself that he is constantly invited to participate in scholarly-oriented activities, and that local people and authorities alike are aware thereof.

\section{Concluding remarks}

For the present paper I have proposed and discussed an approach to the dynamics of ethnographic encounters, which emphasizes the interplay between discourse and authority. I have shown that mediation is a crucial factor to an understanding of ethnographic encounters, given the circumstance that the addressee is not the person ultimately aimed at by my consultant's speech, the latter is not the original source of the propositional content of his speech and is neither responsible for the selection of the thematic domains and specific topics that motivated the interaction. Don Melquíades' recognition of the mediating nature of both his own role and researcher's role allows him to identify his own contribution in a dialog between mediational actors, and to claim authority for such contribution. By engaging in a process of socialization of knowledge and actively creating the best possible conditions for a smooth entextualization process and a successful display of communicative competence, he simultaneously accomplishes a personal goal, reproduces his prestige within and outside his community, and, ultimately, his role as consultant.

Understood in this way - that is, as part of a process of socialization of knowledge which engages the interaction of two mediational actors -, the entextualization process, the locus of Don Melquíades' authority, articulates different mediational dimensions. First, the face-to-face interaction is mediated by a written schedule; second, a chronological mediation takes place between the rehearsal and the recorded (target) interaction. In addition, creating a link that connects the investigator's research needs to the Totonac elders' knowledge involves bridging an interlinguistic and cultural gap, as well as a generational gap. An important element in this bridging endeavor is the frequent comparison between the bygone and the present days. Not only appeals Don Melquíades to a comparison involving different moments in the history of his community, but he also evaluates the advantages and disadvantages of the corresponding beliefs and practices, thereby assuming a clearly agentive role.

Intertextuality accomplishes a crucial function in the shaping of mediational discourse. The fact that Don Melquíades verbal delivery is guided by a written schedule not only implicates the interaction of two texts, but also of two modalities of discourse (verbal/written). Intertextual reference to the research schedule acts as a cohesive device that allows Don Melquíades to move on when the connection between two succeeding topics in the schedule is hard to establish by other means. Simultaneously, intertextual reference accomplishes the function to allocating authority for the topical content of the schedule. Projected intertextuality is a core element of metadiscoursive sections, since a written text: my MA thesis, is overtly acknowledged as the target text of the current interaction.

Linguistic resources used by Don Melquíades to allocate and construct authority consist of metadiscursive elements, be it whole sections, in which a reference is made to the participants and their respective roles, or brief comments scattered throughout the text, in which the source of knowledge or the way in which such knowledge was accessed is identified. The second kind of means used by Don Melquíades for constructing authority and displaying communicative competence (Bauman 1993) is 
discourse form. I have devoted special attention here to cohesion and register consistency. Metadiscursive elements also play a cohesive role, as in those cases in which the kind of speech act involved is made explicit, thereby contributing to the continuity of discourse. In addition, they help to present the emerging speech as a clearly-bounded discourse unit. The result is a unitary text, with opening and closing sections, a careful management of topic changes, and a consistent formal register, evidenced by lexical choice, forms of address and paralinguistic features. These properties are the result of a step by step negotiation of the terms and course of the interaction, including methodological tools and turn economy.

The analysis I have advanced here shows that discourse and interaction in ethnographic encounters can be productively studied from the perspective of authorization and mediation. This approach demonstrates the affinities and peculiarities of this highly emergent and creative kind of discourse, in the context of other discourse forms, such as ritual speech and other performance genres, which have captured a great deal of scholarly attention. Whereas these forms tend to involve repetition or recreation of traditional texts or forms of interaction, the kind of performance discussed here does not involve a preexistent text or even genre, or a process of traditionalization, although similar resources are employed in order to imbue discourse with authority, such as allusion to a prime speaker or entity, a highly reflexive kind of discourse, and disclaimers of performance, among others. As Keane (2004: 434) points out, formal features do not achieve their effects alone or automatically: any account of the effects of linguistic form in actual settings requires analysis of the surrounding social dynamics. In this respect, I have demonstrated that a deeper understanding of discourse and interaction in ethnographic encounters involves the consideration of such broader phenomena as face, prestige and language ideology.

\section{Acknowledgments}

My deepest gratitude goes to Don Melquíades, my consultant, whose critical perspective of field research motivated and made possible the present study. I would also like to thank John W. Du Bois, Mary Bucholtz and Annette Harrison for their valuable input on an earlier version of this paper. Of great benefit were the critical comments and detailed suggestions of an anonymous reviewer. I am grateful to David Rojas for his considerable help with the translation of the Spanish excerpts included in my analysis into English. Of course any remaining mistake or limitation is my own. CONACYT and UC MEXUS supported me with a fellowship throughout my doctoral studies at UCSB, thereby allowing me to develop the first version of the present article. Their help is gratefully acknowledged.

\section{References.}

Bauman, Richard (1977) Verbal art as performance. Prospect Hights, IL:Waveland Press.

Bauman, Richard (1986) Story, performance and event: Contextual studies of oral narrative. Cambridge: Cambridge University Press. 
Bauman, Richard (1990) Contextualization, tradition, and the dialogue of genres. In C. Goodwin \& A. Duranti (eds.), Rethinking context. Cambridge: Cambridge University Press.

Bauman, Richard (1983) Disclaimers of performance. In J. Hill and J. Irvine (eds.), Responsibility and evidence in oral discourse. Cambridge: Cambridge University Press, pp. 182-196.

Bauman, Richard (2004) “Than I can’t tell you”: Negotiating performance with a Nova Scotia Fisherman. In R. Bauman, A world of others' words. Cross-cultural perspectives on intertextuality. Malden, MA: Blackwell, pp. 109-127.

Bauman, Richard (2004) A world of others' words. Cross-cultural perspectives on intertextuality. Maldan, MA: Blackwell.

Bauman, Richard, and Charles L. Briggs (1990) Poetics and performance as critical perspectives on language and social life. Annual Review of Anthropology 19: 59-88.

Bloch, Maurice (1974) Symbols, song, dance and features of articulation. Is religion an extreme form of traditional authority? Archives Européenes de Sociologie XV.1: 55-81.

Briggs, Charles (1986) Learning how to ask: A sociolinguistic appraisal of the role of the interview in social science research. Studies in the Social and Cultural Foundations of Language. Cambridge: Cambridge University Press.

Brown, P., and S. Levinson (1987) Politeness: Some universals in language usage. Cambridge: Cambridge University Press.

Bucholtz, Mary, and K. Hall (2004) Language and identity. In A. Duranti (ed.), A companion to linguistic anthropology. Malden, MA: Blackwell, pp. 369-394.

Cameron, E., P. Harvey, M.B.H. Rampton, and K. Richardson (eds.) (1992) Researching language: Issues of power and method. London: Routledge.

Du Bois, John W. (1986) Self-evidence and ritual speech. In W. Chafe and J.Nichols (eds.), Evidentiality: The linguistic coding of epistemology. Norwood, NJ: Ablex, pp. 313-336.

Duranti, Alessandro (ed.) (2004) A companion to linguistic anthropology. Malden, MA: Blackwell,

Duranti, A., and D.Brenneis (eds.) (1986) The audience as coauthor. Special issue of Text 6.3.

Goffman, Erving (1967) Interaction ritual: Essays in face to face behavior. New York: Doubleday.

Goffman, Erving (1971) Relations in Public: Microstudies of the public order. New York: Harper and Row.

Goffman, Erving (1981) Forms of Talk. Philadelphia: University of Pennsylvania Press.

Haring, Lee (1972) Performing for the interviewer: A study of the structure of context. Southern Folklore Quarterly 36: 383-398.

Hill, Jane, and J. Irvine (eds.) (1993) Responsibility and evidence in oral discourse. Cambridge: Cambridge University Press.

Hymes, Dell H. (1975) Breakthrough into performance. In Dan Ben-Amos \& Keneth S. Goldstein (eds), Folklore: Performance and communication. The Hague: Mouton, pp. 11-74.

Keane, Webb (2004) Language and religion. In A. Duranti (ed.), A companion to linguistic anthropology. Malden, MA: Blackwell, pp. 431-448. 
Labov, William (1972) Sociolinguistic patterns. Philadelphia: University of Pennsylvania Press.

Mannheim, B., and K. Van Vleet (1998) The dialogics of southern Quechua narrative. American Anthropologist 100.2: 326-246.

Maranhao, Tullio (1993) Recollections of fieldwork conversations, or authorial difficulties in anthropological writing. In J. Hill and J. Irvine (eds.), Responsibility and evidence in oral discourse. Cambridge: Cambridge University Press, pp. 260-288.

Martin, J.R. (2001) Cohesion and texture. In B. Schiffrin, D. Tannen and H. Hamilton The Handbook of discourse analysis. Malden, MA: Blackwell, pp. 35-53.

Matoesian, G.M. (1999) The Grammaticalization of participant roles in the constitution of expert identity. Language in society 28.4: 491-521.

Mishler, Elliot G. (1986) Research interviewing: Context and narrative. Cambridge: Harvard University Press.

Paredes, Americo (1977) On ethnographic work among minority groups. New scholar 6.1: 1-32.

Tedlock, Dennis (1983) The spoken word and the work of interpretation. Philadelphia: University of Pennsylvania Press.

Wolfson, N. (1997) Speech events and natural speech. In N. Coupland \& A. Jaworski (eds.), Sociolinguistics. A reader and coursebook. New York: Palgrave, pp. 116-125. 